\title{
A történelem lapjai
}

\section{Fôszerkesztôi beköszöntő}

Journal of Economic Literature (JEL) kódok: B20, N01

Kulcsszavak: gazdaságpolitika, társadalompolitika, Magyarország

Megannyi vezetô, értelmiségi küzd - nyíltan vagy palástolt módon - annak a késztetésének a megvalósításával, hogy a történelem részévé váljon. Közülük a jó szándékúak nyilván azt remélik, hogy az általuk vagy az irányításuk alatt létrehozott javak, rendszerek, alkotások, tudományos eredmények olyan léptékúvé emelkednek, amelyekre az emberek majd évek, évtizedek, évszázadok múltán is emlékezni fognak, jótékony hatásukat élvezik. A nagyszerúségük a könyvekbe kerül majd, melyeket az utókor szívesen lapozgat, s a továbblépés kiindulópontjai lesznek, hivatkozási alappá válnak. Nem kevésbé fontos azon emberek munkája sem, akik nap mint nap az eke szarvánál, az esztergapadnál állnak, három múszakban dolgoznak, s a családjuk fenntartására, gyermekeik nevelésére összpontosítják az erôiket. Igaz, szeretjük a látványos dolgokat. Talán mindenki szereti. De e mindennapi küzdelem a családok millióinál teszi a társadalmat társadalommá és fenntarthatóvá. Az értékek, hagyományok, a szeretet, az anyanyelv közvetítése, ápolása csakis a társadalom legkisebb, de legfontosabb sejtjei, a családok létezése által válhat valóra.

Teljesítményorientált világunkban bizony elsikkadnak a hétköznapi hôstettek. E téren (is) „nyugatias nemzet” lettünk. Jó pár éve azonban a kormány részérôl adódott a felismerés, hogy a magyar nemzet évszázadai végesek, ha elfogy a népesség, a szeretet, a hagyomány, illetve a kívántnál erôsebb mértékben asszimilálódik a magyarság. Így a kiszámíthatóbb s a korábbi évtizedeknél lényegesen kedvezóbb nemzetgazdasági teljesítmények bázisán, az állami költségvetési források felhasználásával széles tere teremtődött meg a családi adókedvezményeknek, a család- és otthonteremtési támogatásnak, s általuk a gyermeknevelés anyagi terhei mérséklésének. Jóllehet, csak pénzügyi-költségvetési eszközökkel a gyermekvállalási hajlandóságot nem lehet érdemben fokozni, ezért a családokra hárul az a szerep, hogy a mindennapjaikba a család- és gyermekközpontúságot beépítsék, olyan értékrendet formáljanak maguk körül a gyermekeik nevelése során is, amely nem az egó, hanem egy-egy pici közösség (család) kibővítését, egyúttal szellemi és szeretet téren is a kiteljesedést szolgálják. Mert igaz, hogy a puskagolyók elé történô - néha értelmetlen - kiállás, a kimagasló sportteljesítmények, szellemi alkotások, egyéni és kollektív boldogulás, „ütésálló” birodalmak létrehozása a történelemkönyvek lapjaira 
méltóak, ám most nekünk, magyaroknak azzal kell szembesülnünk, hogy ha a népesedési folyamatok érdemben nem változnak, bizony kimagasló teljesítményeink fogadó- $\mathrm{s}$ olvasótábora, a potenciális hagyományốrzôk serege a jövôben megfogyatkozhat.

A kedvezôtlen folyamatok alakítója sok esetben a restség, a tunyaság, a szeretni nem tudás. De mindig vannak, akik a sebeket nem bekötözik, hanem arra sót hintenek. Akadnak nyilván gonosz erốk, a rosszak, akik erôszakkal hódítanak, másokat szellemileg és fizikailag leigáznak, s mivel általában rossz dolgokon törik a fejüket, rossz dolgokat hoznak létre, amelyek aligha válhatnak az emberiség, a társadalom javára. A háborúkat kirobbantók, a találmányokat, a hatalmukat a humánum ellen fordítók e körbe tartoznak. A világ végül is a jó és a rossz párharca, örökös küzdelme marad. Aztán vannak a gazdasági korszakok, birodalmak, kurzusok, amelyek átfogó rendszertani jellemzókkel, kohézióval bírtak, bírnak, s a történelmi tananyagnak ugyancsak részei. Mulandók nyilván e „komplexumok” is, mint ahogy a Nyugatrómai Birodalom is az lett, s az azt követố új barbárság kora is elmúlt, aztán a reneszánsz, a gớzgép felfedezése, vele a kapitalizmus, az eredeti tôkefelhalmozás gazdasági nyitánya is a múlté lett. Mi még láttuk közelrôl a tervgazdaságot, az 1968-as új gazdasági mechanizmust is felcsillanni, a piacgazdasági átmenetbe is „belekóstoltunk”, s fura íze volt, így magunk mögött hagytuk. Kilencedik éve éljük, tapasztaljuk, formáljuk, mások pedig ízlelgetik az aktív állammodellt, az állam erôsebb gazdasági befolyásolása alatt múködô gazdaság- és társadalompolitika mindennapjait, a vállalatoknál és a társadalomnál megfogható hatásait. Bennünk, akik az alakítói vagyunk, bizony felmerül, hogy maradandó lesz-e. Évtizedek, évszázadok múltán lesz-e olyan korszakos jelentôségú, mint az 1867es kiegyezést követố dualizmus volt? Megél-e ugyanúgy (legalább) negyven évet, mint a dualizmus vagy a szocialista tervgazdaság, vagy a negyed évszázados életkort éppen abszolváló piacgazdasági átmenet?

„Figyelemre méltóak” azok a rendszerek, amelyek gazdasági fejlesztésük által a társadalom anyagi és szellemi életének javítására, a nemzet politikai függetlenségének, nagyságának az erôsítésére törekszenek. Ilyen volt az 1848-1849-es szabadságharc leverése utáni neoabszolutizmus évtizedeit követô, 1867-es kiegyezéssel megnyíló gazdasági és társadalmi fellendülés, melynek - sajnos - az elsố világháború vetett véget, $\mathrm{s}$ az ország is szétesett. Nemes küzdelem volt a dualista magyar állam részérốl, a modernizáció érdekében, az államvezérelt kapitalizmus kiépítésének végigvitele, mint ahogy a két világháború közötti időszaké is, különösen az 1921 és 1931 közötti bethleni konszolidáció intervalluma, amely a békés újjáépítés, no és persze az elszenvedett igazságtalanságok orvoslása érdekében munkálkodott, és szinte teljes nemzeti egység mentén múködött. Politikai pártok, gazdasági érdekcsoportok, társadalmi osztályok közös törekvése volt a Trianon okozta sérelmek helyrehozatala. A munkások körében szervezốdô politikai pártok „lemondták” a sztrájkokat, tüntetéseket, szerzôdésben vállaltan nem éltek e jogaikkal, ezzel is erôsíteni akarták a revansra összpontosító kormány múködését. Tervgazdaság, piacgazdasági átmenet s megannyi illúzió, amely Magyarország adottságaitól, hagyományaitól, a társadalom igényeitốl eltérő gazdasági és társadalmi viszonyokat kívántak (kényszerbőll) importálni, mindezek szertefoszlottak. Az eladósodottaknál is eladósodottabbak lettünk. 
Kérdés, dilemma, hogy a 2010 utáni kurzus a négyévente ismétlődô választási győzelmeket kiharcoló módozatként marad-e fenn az emlékezetben, vagy a parlamenti demokrácia szabályai szerint ismétlődô választások bázisán létrejövô kormányok egy átfogó gazdasági korszakot alapoznak meg? Tehát „összeáll-e” a „négyévekből” az önálló, a korábbi kurzusoktól meghatározó jegyeiben különbözó és eredményes évtizedek sokasága, s ennek hatására egy gazdasági és társadalmi értelemben felzárkózott, fejlett magyar modell. A végeredményt nyilván nem tudhatjuk, de formáljuk, hogy így legyen. Biztató, hogy az elmúlt százötven évben azok a kurzusok voltak sikeresek és emlékezetesek, amelyek piacgazdasági viszonyok között gazdasági és társadalmi bôvülést egy államvezérelt gazdaságpolitika mentén tudtak megvalósítani. Egyértelmúen ilyen volt a magyar dualizmus és többé-kevésbé a bethleni konszolidáció idôszaka is, mint ahogy a mostani, a 2010 utáni is e sorozatba illeszkedik.

Bár a jelenlegi metódus, kormányzati ügyek nem mindenkinek kedvesek. Állítják is, hogy nagyjából ugyanannyi dollárban a GDP-teljesítményünk, mint tíz évvel ezelôtt. Hangsúlyozzák, hogy a mostanit majd hétszázötvenezer munkavállalóval többen állítjuk elô, így a nemzetgazdasági teljesítményünk csak forintban elszámolva több, ami által a rendszerünk nem hatékony, nem lesz fenntartható. Persze megválaszolandó, hogy ha többen és többet dolgozunk, miért nem emelkedik a dollárban is kimutatott bruttó hazai termék? Nos, azért, mert a forint elleni folyamatos támadások, a spekuláció gyengíti a nemzeti valuta árfolyamát. És még egy kritika, ellenvetés ellenünk: hét éve ugyan folyamatos a reálbér-emelkedés, duplájára nôtt a minimálbér, emelkednek a szociális juttatások, ám a forintban elszámolt jövedelem egyharmadát elviszi a forint romlása, a kedvezôtlen árfolyam. Errôl a kormány és a jegybank aligha tehet, mert akik rontják a forintot, százszoros, ezerszeres mértékben erôsebbek. Több pénzük van akár a spekulációra is, mint a polgári kormánynak vagy a Magyar Nemzeti Banknak. Márpedig a rendszer fennmaradását a kormányzati fiskális politika és a vele egy irányba tartó jegybank eddig kiválóan szolgálta, hiszen stabil a gazdaság. Aki a bérek, szociális juttatások emelkedését, a vállalatok gyarapodását, a család- és otthonteremtési támogatás további bôvülését reméli, az erre a gazdaságpolitikára ráutalt, érdeke, hogy fennmaradjon. De nyilván tovább kell lépni a gazdaságirányításban. Óriási tartalékok vannak a kis- és középvállalati szektorban, de zömüknek a mérete annyira kicsi, hogy még a minimálbér-emeléseket is nehezen tudja kigazdálkodni. Gyengék a fejlesztési kapacitásaik, de fóleg a motivációjuk az innovációra. E stratégiai terület nagyobb kohéziója további lendületet adhat, mint ahogy a nemzetközi vállalatokkal a további stratégiai partnerépítési folyamat is. Az olyan kényes kérdésekre is, mint a vállalatok és a munkavállalók közötti béralku folyamata, a Pénzügyminisztériumnak a jövôben nagyobb figyelmet kell fordítania. Mert bizony egy állam vezérelte piacgazdaságban az állam s a nevében eljáró pénzügyi tárca, mint a gazdaság szabályozásáért felelôs, nemcsak a minimálbér- és garantáltbérminimum-tárgyalások koordinációjára hivatott, hanem a piaci alapon múködô vállalkozások és munkavállalók együttmúködésének, a minimálbéreken túli bérmegállapodások elôsegítésére is. Így volt ez a Monarchia idején is. Az ipartámogatási törvények ${ }^{1}$ az ipartestületek létrejöttét (is) szorgalmazták, melyek által az ipar szervezettségét és az iparban foglalkoztatottak érdekeit erôsítette az állam. 
Tehát a gazdasági teljesítmények fenntartása, új növekedési faktorok bevonása, a kisvállalatok integrációjának kormányzati-jegybanki eszközökkel történô elósegítése, a munkavállalói érdekek még erôsebb állami felkarolása és a „kimúvelt emberfôkben” rejlő tudás szervezettebb társadalmi hasznosítása, a kutatóhelyi teljesítmények nagyobb hatékonyságúvá tétele lehet az újabb lendület forrása. A fenntarthatóság, a gazdasági korszak formálása most ezekre a kihívásokra célszerú hogy fókuszáljon.

Az eloottünk álló időszak most a nyugodt építkezésé. A forint elleni spekulációk ellenére is van „töltet” a fejlódéshez, hiszen az egyharmad „elkonfiskálása” ellenére is pozitív egyenlegú a devizában elszámolt bér-jövedelem gyarapodás, ${ }^{2}$ nem is beszélve a forintban kimutatott, hét év alatti majd kétszeres reálbér-emelkedésrôl. Stabil az állampénzügyi szektor, és öt százalék körüli a gazdasági növekedés. A Polgári Szemle társadalomtudományi folyóirat küldetése pedig, hogy a Magyar Tudományos Akadémia nem túlértékelt tudományos lapbesorolása ellenére, tovább növeljük a megjelenô dolgozatok tudományos módszertanbeli pluralizmusát, amellyel a valóság, a körülöttünk zajló folyamatok még objektívebb feltárása válik lehetôvé. Belföldi olvasóinknak szánt magyar nyelvú, a 2019-ben negyedik alkalommal megjelenő angol nyelvú, illetve az elsố alkalommal megjelenô kínai lapszámunkban is erre törekszünk.

Érdemes Polgári Szemlét olvasni!

Prof. dr. Lentner Csaba

egyetemi tanár, főszerkesztő

\section{JEG Y ZETEK}

1 Lásd például: 1884: 17. tc., 1890: 14. tc.

2 Azon „egyszerú” tényrôl se feledkezzünk meg, hogy az 1995-ös Bokros- és a 2006-os Gyurcsány-, majd Bajnai-csomag idején - forintban elszámolva - 10-30 százalékkal csökkentek a nyugdíjak, családok százezreitôl vonták meg a családi pótlékot és más állami juttatásokat, sốt tízszázalékos munkanélküliség volt, tízezerszámra mentek tönkre a hazai vállalkozók. És ha forintban - mindannyiunk emlékezete szerint estek a jövedelmek, akkor vajon dollárban, már csak a nemzeti valuta folyamatos és tervszerú leértékelésének hatására (Bokros Lajos, Surányi György devizapolitikája), vagy a 2007-2008-as világgazdasági válság elôtt már „tetszhalott” állapotban lévô költségvetés-politika következtében a dollárban elszámolt jövedelem-visszaesés milyen (további) zuhanást eredményezett? Ó, boldog békeidôk?! 